\title{
Economic Feasibility of Electrical Power Cogeneration from Forestry Biomass in an Engineered Wood Panel Industrial Facility
}

\author{
André Gustavo Oliveira Souza, Franklin de Souza Barbosa, \\ Maura Seiko Tsutsui Esperancini, Saulo Phillipe Sebastião Guerra
}

\begin{abstract}
The use of sugarcane bagasse, straw, and chaff for electrical power generation in sugar-ethanol mills has been established; more recently, the recovery of forest biomass has been increasing in an attempt to reduce the use of fossil fuels and to increase electrical power generation focused on self-consumption. The potential for power generation in this segment is considerable, but the use of biomass in cogeneration processes depends on an attractive return on investments. This study was designed to analyze the economic feasibility of investment in thermal and electrical power generation equipment that makes it possible to use forest and logging residues and wood chips to replace the current gas-fired power generation in an engineered wood panel industry facility (Scenario 1) or investment only in thermal generation equipment (Scenario 2). Results showed that the investment to replace natural gas with forest biomass is economically viable not only for the generation of both types of energy but also for the generation of thermal energy itself. High costs of energy inputs such as natural gas and electricity for the industry explain the results, despite the requirement for high investments in cogeneration systems.
\end{abstract}

Keywords: residues usage, renewable energy, thermal generation, power generation

\section{Introduction}

The lignocellulosic biomass can be converted into a variety of chemicals and energy, including solid, liquid, and gaseous fuel, into processes for the generation of thermal, mechanical, and electrical energy (Londo et al. 2018). In addition to the environmental liabilities caused by the generation and disposal of waste, there is also an economic liability because the power potential of biomass from forestry wastes is generally very high and, as a rule, is not used. Brazil's power matrix uses one of the highest percentages of renewable power sources. While this share is $13 \%$ on average worldwide, it reached $43.5 \%$ in Brazil in 2016, especially for products derived from sugarcane biomass and hydraulic power (EPE 2018). In the Brazilian electricity matrix, the sugar-alcohol sector pioneered the use of bagasse and sugarcane straw to generate electrical power for self-consumption and for sale to distributors. Due to the volume produced, Brazilian chaff (ground straw derived from sugarcane) is being widely used to produce electricity. With production volume intensification, resources that were little used until recently, such as sugar cane straw, are also being widely used for electricity production, as other sectors have also evolved in turning waste into renewable energy sources (Santos 2018). The forestry sector has excellent potential for utilizing waste biomass. The forest-based industry in Brazil (the pulp and paper, timber, and furniture industries) includes 95 biomass-powered plants producing approximately $3.1 \mathrm{GW}$, corresponding to a share of $7.6 \%$ in the national electricity matrix (ANEEL 2018). One of the residues used for biopower production in the forestry sector is black liquor, which is the waste from pulp and paper production $(1.9 \mathrm{GW})$; it is the second most important (14.94\%) biomass source and occupies a position second only to sugarcane bagasse (Pedroso et al. 2018). Still, forest residues are used 
to generate energy through burning in boilers (63.2\%), and $29.4 \%$ are being reused as raw material by other companies (IBÁ 2019). On average, the Brazilian timber processing industry has a low use of potentially energetic waste; approximately $40 \%$ of this waste is used, and the remainder is discarded (Brand 2010). It is estimated that forest waste production in Brazil is in the order of 17 million cubic meters per year (FAOSTAT 2018). As power input costs have continued to increase, the industries have sought the use of industrial and forest residues as an alternative power source. However, increased biomass use depends on the economic feasibility of investments for the conversion of biomass into power; the knowledge of the proximate composition, heating value, moisture content, and basic density being essential (Eufrade-Júnior et al. 2018). These properties are strongly related to a better option for energy use and its economic feasibility of using forest biomass to generate heat and electricity, impacting directly on the handling, transportation, and energy conversion systems costs (Akthari et al. 2014, Sosa et al. 2015, Eufrade-Júnior et al. 2017). This study aims to analyze the economic feasibility of an investment project, in which forest residues, wood processing tailings, and wood chips are produced in an industry that manufactures engineered wood panels, in two scenarios. The first scenario considered the investment to replace the natural gas consumption and cogenerate 5.4 MW of electric energy; the second scenario only considered the thermal energy equipment for replacing the natural gas.

\section{Materials and Methods}

\subsection{Object of Study}

The company that manufactures engineered wood panels is located in the interior of the state of São Paulo. It is a large-scale organization that operates at the production capacity of $700000 \mathrm{~m}^{3}$ year ${ }^{-1}$ of engineered wood panels. At present, the company has an internal power generation system (only thermal energy not electricity) that partially meets its needs, i.e., it acquires part of the necessary power from the market, consuming $2.4 \mathrm{~m}^{3} \mathrm{~h}^{-1}$ of natural gas and $2000 \mathrm{~kg} \mathrm{~h}^{-1}$ of external biomass to maintain the process of manufacturing engineered sheets in one of its lines. The investment project under study aims to analyze the economic feasibility of investment in thermal and electrical power generation equipment that makes it possible to use forest and logging residues and wood chips to replace the current gas-fired power generation in an engineered wood panel industry facility (Scenario 1) or investment only in thermal generation equipment (Scenario 2). As this is a case study, the data used for the execution of this study originate from primary sources derived from management and from technical information on the company itself. According to the proposed project implementation, the biomass flow should increase to $18200 \mathrm{~kg} \mathrm{~h}^{-1}$, thus keeping the power production system in equilibrium. The increased biomass will be made available by the company itself because the forest operations and the slab processing system themselves produce a surplus of this material. When there is a deficiency in the amount of biomass available from the manufacturing process, it will be supplied by wood chips diverted from the sheet production process itself.

\subsection{Methodology}

In this type of large-scale enterprise, decision-making involving considerable sums of resources is intrinsic. As a rule, such resources are scarce, and optimizing the choice of future economically advantageous investments is necessary considering that future net earnings should exceed the expenses incurred at present. In the current system, the combustion chambers consume natural gas exclusively, in which consumption of $2400 \mathrm{~kg} \mathrm{~h}^{-1}$ is assumed. Under these conditions, forestry biomass consumption is restricted to the only boiler in the system, implying the use of only $2000 \mathrm{~kg} \mathrm{DB} \mathrm{h}^{-1}$. In the proposed generator implementation, the system includes the installation of a boiler that can be used to burn both residual and forestry biomasses. Thus, biomass consumption would increase from $2000 \mathrm{~kg} \mathrm{DB} \mathrm{h}^{-1}$ to $18200 \mathrm{~kg} \mathrm{DB} \mathrm{h}^{-1}$ (biomass that would be readily available in the form of wood chips, due to production surplus), and there would be an immediate interruption of natural gas consumption and the generation of 5.4 MW of electricity would be available for sale to the electricity grid or for consumption by the company itself (Scenario 1). In Scenario 2, it was considered just to replace natural gas consumption. Several steps in the process of producing engineered wood veneers can generate wood dust and waste destined for burning and generating thermal power and steam. The lower heating values (LHVs), presented by the wood panel enterprise, was considered in this study for the calculation, and conversion effects were the following: eucalyptus bark $\left(7.2 \mathrm{MJ} \mathrm{kg}^{-1}\right)$, eucalyptus $\left(8.9 \mathrm{MJ} \mathrm{kg}^{-1}\right)$, GMO oil (40.3 MJ kg-1), and natural gas $\left(45.4 \mathrm{MJ} \mathrm{kg}^{-1}\right)$. For the wood density, we considered $450 \mathrm{~kg} \mathrm{~m}^{-3} \mathrm{DB}$. The most expensive items are the acquisition of equipment and its assembly. The equipment is imported, and its cost may increase as a function of exchange rates and imports. The project implementation schedule is 14 months after the release of financial resources. Equipment manufacturing and assembly time are included in this period. 


\subsection{Initial Investments}

In the investment analyses, it is necessary to budget the initial investments, the system operating costs, and the venture revenues. Based on the capital budget, it is possible to estimate discounted cash flow (DCF) and economic feasibility indicators, as shown below. The necessary investment in equipment modifications is US\$ 22.728 million. For an investment of this magnitude, Brazilian companies usually opt to raise funds from the Brazilian Development Bank (BNDES), which offers specific modalities for the use of renewable power and interest rates lower than those charged by the financial market. In this study, the possibility of financing or fiscal incentives was not studied. Table 1 shows the investments required to modify the current system for use as a wood waste utilization system.

The currently installed equipment has a thermal capacity of $110 \mathrm{MJ} \mathrm{s}^{-1}$, distributed as follows: grids $\left(42 \mathrm{MJ} \mathrm{s}^{-1}\right)$, suspension $\left(17 \mathrm{MJ} \mathrm{s}^{-1}\right)$, and gas $\left(51 \mathrm{MJ} \mathrm{s}^{-1}\right)$. With a production of $700000 \mathrm{~m}^{3}$ year ${ }^{-1}$ of products, the production system has an average consumption of $85 \mathrm{MJ} \mathrm{s}^{-1}$ of power. The power consumption is distributed in the process as follows: $29 \mathrm{MJ} \mathrm{s}^{-1}$ in the form of steam, $44.8 \mathrm{MJ} \mathrm{s}^{-1}$ in the form of hot gas, and $10.2 \mathrm{MJ} \mathrm{s}^{-1}$ in the form of thermal oil heating. This consumption is estimated; the actual consumption can vary according to the external temperature, humidity of materials being consumed, and the product to be produced, consuming more or less power per unit of the finished product. The waste and wood dust that compose the biomass used in cogeneration are generated at various points of the production process. These materials, which have different characteristics, include wood in the form of fibers, sawdust, sanders, and waste from slabs with different particle sizes. Each of these materials will have specific burning characteristics and specific moisture content (Souza et al. 2012). To increase bio-

Table 1 Initial outlay for both scenarios

\begin{tabular}{|l|c|c|}
\hline \multirow{2}{*}{\multicolumn{1}{|c|}{ Description }} & Scenario 01 & Scenario 02 \\
\cline { 2 - 3 } & Value, US\$ & Value, US\$ \\
\hline Project detail & 75758 & 49000 \\
\hline Boiler biomass & 13878788 & 8805000 \\
\hline Electrical power generator & 3545455 & - \\
\hline Equipment electromechanics assembly & 2727273 & 870000 \\
\hline Civil works & 1363636 & 390000 \\
\hline Documentation and licenses & 75758 & 32000 \\
\hline Contingency, 5\% & 1060606 & 500000 \\
\hline Total & 22727273 & 10646000 \\
\hline
\end{tabular}

mass use in electrical power cogeneration, it is necessary to acquire new equipment that will replace the system that is currently used for hot gas production and thermal oil heating. This equipment will consist mainly of a boiler for burning biomass and an electrical power generator. Also, other costs related to the project details, electromechanical assembly of the equipment, civil works, licenses, and remuneration were predicted in the initial investment phase. A contingency of $5 \%$ of the initial investment value is also predicted in this phase to cover possible risks related to implementing the investment. The investment in the new system predicts a sizing of the electrical power generator of 5.4 MW, and the steam consumption of the sheet metal manufacturing process demands $29.2 \mathrm{MJ}$; therefore, the powergenerating equipment must have a steam escape that can meet the demand of the production process.

\subsection{Operational Costs of the System}

The costs related to salaries, materials, outsourced activities, operations, and other items were estimated to operationalize the system. The operating costs of the current system refer to the teams that will work in the sector, the new technicians who will need to be contracted to operate the new equipment, and all charges related to people in operation. The cost of materials refers to items of direct or indirect consumption that will be used directly in steam generation after implementing the generator. Regarding steam generation and system cooling, the cost of the chemicals used to treat the water, oils, and greases used to lubricate the equipment and spare parts to replace those with higher wear, such as control valves, manual valves, bearings, and fuels, were considered. Regarding the outsourcing activities demanded by the project, the following are included: service providers in the areas of mechanical, electrical, and civil maintenance, cargo movement in general, general expenses associated with obtaining environmental licenses, certifications and insurance, and technical consultants. Operating costs were also considered. These are the costs related to the rental of equipment, disposal of waste, and the collection and disposal of the ash generated in the biomass burning process. Operating costs also include professional training, expenses related to information technology, office supplies, and internal and external communication.

\subsection{Additional Income from the Project}

The benefits considered are the monetary gains related to cost savings from natural gas and electricity acquisition after deducting the additional biomass and operational costs. The amount of natural gas acquired in one year of operation in the current system was used to estimate cost savings, and it was priced based on the 
moving average of the stock in August 2017. In the same way, the amount of electricity acquired in one year was estimated and priced based on its open market value in August 2017. Possible oscillations in the market prices for natural gas and electricity were not considered. Expenditure on the acquisition of biomass necessary to replace natural gas in this process was deducted from the estimated gains. Wood processing includes the cost of freight transport from the field to the processing unit, payment of employees, materials, depreciation of machines, direct tools, and other costs related to the process. The increase in the operating cost of the new biomass burner system is low relative to the total operating cost of the current system. Some of the current operators must be reallocated to meet the demands of the new operation. The increase in cost is due to the necessity of hiring experts in connection with the new electrical power generation and maintenance system and to the other expenses shown below.

\subsection{Planning Horizon, Minimum Acceptable Rate of Return (MARR), and Economic Feasibility Indicators}

A 20-year planning horizon was considered because this is the generator expected lifetime, and a hurdle rate (HR) of $13.5 \%$ was assumed. This rate is comparatively high relative to the market interest rates, but considering the risk-free cash flows, it was decided to include a higher HR that would incorporate all project risks. The following economic feasibility indicators were estimated: Net Present Value (NPV), Internal Rate of Return (IRR), and Economic Payback (EPB).

\subsection{Net Present Value (NPV)}

Through the representation of the project relevant characteristics based on the same common denominator, i.e., cash flow, the NPV calculation makes it possible to assess the feasibility of investments and estimate the value to be generated for the shareholder (Brealey and Myers 2019). The investment project NPV is the sum of the present values of each of the cash flows, both positive and negative, that occur throughout the project life. The general determination for the NPV method is Equation (1).

$$
N P V=\sum_{\mathrm{j}=\mathrm{i}}^{\mathrm{n}} \frac{C F_{\mathrm{j}}}{(1+i)^{\mathrm{j}}}-C F_{0}
$$

$C F_{j} \quad$ cash input or output values in each period

$C F_{0}$ initial investment value

$j \quad$ time period, years

$i \quad$ rate of discount of the project.
The rule for making decisions on NPV for independent projects is to adopt investment projects with positive NPV value as feasible.

\subsection{Internal Rate of Return (IRR)}

The IRR corresponds to the discount rate that zeroes in the NPV of a project (Calôba and Neves 2008). Typically, the initial cash flow is represented by the investment value. The other cash flows indicate the amounts of revenue or expenses due. The IRR can be viewed as the annual capitalized return rate that the company will obtain if it invests in the project and receives the expected cash inflow (Gitman 2011). The internal rate of return (IRR) is given by Equation (2).

$$
I R R=i \mid \sum_{\mathrm{j}=1}^{\mathrm{n}} \frac{C F_{\mathrm{j}}}{(1+i)^{\mathrm{j}}}=C F_{0}
$$

$C F_{\mathrm{j}}$ cash input or output values in each period

$C F_{0}$ initial investment value

j time period, years

$i$ discount rate of the project.

Considering that the cash values occur at different times, it is possible to conclude that the IRR method, when taking money into account over time, actually expresses profitability if it is an application and cost in the case of cash flow financing (Assaf Neto 2001). For this reason, to be economically feasible, the IRR of an investment project must exceed the minimum return expected by the investor, which is given by the HR.

\subsection{Economic Payback (EPB)}

Economic payback is the repayment time of the investment or loan, i.e., the number of periods required to recover the investment or the time required for the investment to clear its accumulated flow (Calôba and Neves 2008). The Economic Pay Back $(\mathrm{EPB})$ is described by Equation (3).

$$
E P B=n \mid \sum_{\mathrm{j}=0}^{\mathrm{n}} \frac{C F_{\mathrm{j}}}{(1+i)^{\mathrm{j}}}=0
$$

$C F_{\mathrm{j}} \quad$ cash input or output values in each period

$j$ time period, years

$i \quad$ discount rate of the project.

\section{Results}

\subsection{Energetic Flow}

As previously described, the new system predicts the replacement of the current system by a boiler and generator system that is capable of generating 
Table 2 Energetic flow and mass fluxes

\begin{tabular}{|c|c|c|c|c|c|}
\hline & & & $\begin{array}{l}\text { Current } \\
\text { scenario }\end{array}$ & $\begin{array}{c}\text { Scenario } \\
01\end{array}$ & $\begin{array}{c}\text { Scenario } \\
02\end{array}$ \\
\hline \multirow{4}{*}{$\stackrel{\underline{\varrho}}{\underline{\Sigma}}$} & Internal biomass & MW & 31.1 & 31.1 & 31.1 \\
\hline & Sawdust & MW & 20.0 & 20.0 & 20.0 \\
\hline & External biomass & MW & 9.3 & 44.8 & 34.6 \\
\hline & Natural gas & MW & 25.3 & 0.0 & 0.0 \\
\hline \multirow{4}{*}{$\begin{array}{l}\frac{5}{5} \\
\frac{2}{5}\end{array}$} & Steam & MW & 29.2 & 29.2 & 29.2 \\
\hline & Thermal oil & MW & 10.2 & 10.2 & 10.2 \\
\hline & Hot gas & MW & 44.8 & 44.8 & 44.8 \\
\hline & Electricity & MW & 0.0 & 5.4 & 0.0 \\
\hline 芫 & & $\%$ & & 53 & 95 \\
\hline
\end{tabular}

${ }^{*}$ CE - conversion efficiency

saturated steam at $85 \mathrm{MPa}$ pressure. It also quantified the fluxes in mass and the power of residual biomass from wood processing (Table 2).

\subsection{Additional Operating Costs}

For the sheet manufacturing process, there is no increase in the operational costs of the new equipment, although, in the auxiliary processes of boiler operation and asset maintenance, operational costs of approximately US\$ 819000 per year are predicted. The operating costs of the new process are aligned with the current production costs. The increases will be negligible concerning the total operation because the sector has a structured team that will be transferred to the system with power generators; the increase in operating cost

Table 3 Additional operational expenses in both scenarios

\begin{tabular}{|l|c|c|}
\hline Description of operating costs & $\begin{array}{c}\text { Year values } \\
\text { US\$ }\end{array}$ & $\begin{array}{c}\text { Year values } \\
\text { US\$ }\end{array}$ \\
\hline Salaries, charges, and legal & 281000 & 144000 \\
\hline General materials & 271000 & 146000 \\
\hline Third-party activities & 197000 & 144000 \\
\hline Operation & 63000 & 24000 \\
\hline Other & 7000 & 7000 \\
\hline Total costs & 819000 & 465000 \\
\hline
\end{tabular}

will occur through the hiring of specialized engineers (Table 3).

The additional operating costs are equivalent to $3.6 \%$ of the total investment value. The estimated value for the item operations and maintenance of assets $(\mathrm{O} \& \mathrm{M})$ is $5 \%$ of the total investment value (Tomalsquim 2016).

\subsection{Additional Income from the Project}

Table 4 shows the predicted economic benefits of the project due to natural gas and electricity cost savings, discounting the value of the additional consumption of forestry biomass required for equipment performance, as well as the increase in costs associated with system operation and maintenance. The results indicate an annual monetary benefit of US $\$ 4.55$ million per year in Scenario 1, and US\$ 2.46 in Scenario 2.

\subsection{Cash Flow, Discounted Cash Flow, Planning Horizon, Minimum Acceptable Rate of Return, And Economic Feasibility Indicators}

With additional investment data, the costs and expenses for operating systems and the economic benefits of investing in both scenarios, cash flow, and discounted cash flow data, using a discount rate of 13.5\%, are described in Table 5.

From the discounted cash flows, the economic viability indicators were obtained from those shown in Table 6.

It has been found that such investment is feasible based on both investment plans that predict recovering of the initial investment in a few years, a positive Net Present Value (NPV), and an Internal Rate of Return (IRR) higher than the Hurdle Rate (HR). Using the IRR, an indicator that does not depend on HR, it appears that the production of thermal energy alone is economically more viable than the investment with

Table 4 Cost/benefit project analysis including additional costs

\begin{tabular}{|c|c|c|}
\hline & Scenario 01 & Scenario 02 \\
\hline Project benefits & $\begin{array}{c}\text { million US\$ } \\
\text { year }^{-1}\end{array}$ & $\begin{array}{c}\text { million US\$ } \\
\text { year }^{-1}\end{array}$ \\
\hline Savings with natural gas, MW & 6.36 & 6.36 \\
\hline Savings with electricity, MW & 3.32 & -3.32 \\
\hline Additional cost with biomass, $103 \mathrm{~kg}$ & -4.31 & -1.89 \\
\hline Additional cost with labor, US\$ & -0.82 & -0.47 \\
\hline Biomass sales, US\$ & 0 & 1.77 \\
\hline Total benefits, US\$ & 4.55 & 2.46 \\
\hline
\end{tabular}


Table 5 Summarized cash flow for both scenarios

\begin{tabular}{|c|c|c|c|c|}
\hline \multirow{2}{*}{$\begin{array}{c}\text { Time } \\
\text { period } \\
\text { years }\end{array}$} & $\begin{array}{c}\text { Cash flow } \\
\text { US\$ }\end{array}$ & $\begin{array}{c}\text { Siscounted } \\
\text { Cash flow, } \\
\text { US\$ }\end{array}$ & $\begin{array}{c}\text { Cash flow } \\
\text { US\$ }\end{array}$ & $\begin{array}{c}\text { Discounted } \\
\text { cash flow, } \\
\text { US\$ }\end{array}$ \\
\hline 0 & -22727273 & -22727273 & -10646000 & -10646000 \\
\hline 1 & 4550240 & 4009022 & 2458258 & 2165866 \\
\hline 2 & 4550240 & 3532178 & 2458258 & 1908252 \\
\hline 3 & 4550240 & 3112051 & 2458258 & 1681279 \\
\hline 4 & 4550240 & 2741896 & 2458258 & 1481303 \\
\hline 5 & 4550240 & 2415767 & 2458258 & 1305113 \\
\hline 6 & 4550240 & 2128429 & 2458258 & 1149879 \\
\hline 7 & 4550240 & 1875268 & 2458258 & 1013110 \\
\hline 8 & 4550240 & 1652218 & 2458258 & 892608 \\
\hline 9 & 4550240 & 1455699 & 2458258 & 786438 \\
\hline 10 & 4550240 & 1282554 & 2458258 & 692897 \\
\hline 11 & 4550240 & 1130004 & 2458258 & 610482 \\
\hline 12 & 4550240 & 995598 & 2458258 & 537870 \\
\hline 13 & 4550240 & 877179 & 2458258 & 473894 \\
\hline 14 & 4550240 & 772845 & 2458258 & 417528 \\
\hline 15 & 4550240 & 680921 & 2458258 & 367866 \\
\hline 16 & 4550240 & 599930 & 2458258 & 324111 \\
\hline 17 & 4550240 & 528573 & 2458258 & 285560 \\
\hline 18 & 4550240 & 465703 & 2458258 & 251595 \\
\hline 19 & 4550240 & 410311 & 2458258 & 221670 \\
\hline 20 & 4550240 & 361507 & 2458258 & 195304 \\
\hline
\end{tabular}

Table 6 Economic feasibility indicators for the project

\begin{tabular}{|l|c|c|}
\hline Project Parameters and Indicators & Scenario 01 & Scenario 02 \\
\hline Initial investment, US\$ & 22727273 & 10646000 \\
\hline Project duration, years & 20 & 20 \\
\hline Net present value, US\$ & 8300380 & 6116626 \\
\hline Internal rate return, \% & 19.45 & 22.71 \\
\hline Economic payback, years & 9 & 7 \\
\hline
\end{tabular}

the inclusion of electricity generation in the system. The NPV for the production of thermal energy alone will be higher than the NPV of Scenario 1 when the $\mathrm{HR}>16.5 \%$, which is the Fisher Rate.

\section{Discussion}

The results show that using forestry biomass to produce thermal energy or/and electricity, although requiring a high initial investment, is economically fea- sible, as indicated by the financial criteria of positive NPV and IRR>HR for both scenarios. Even the return on the initial investment occurs over a period that is shorter than the project time horizon in both scenarios. It should be noted that an HR used in this study is higher than the basic interest rate of the Brazilian economy $(6.5 \%$ per year), which is explained by the risks involved in these investment projects, especially concerning the prices of energy inputs. Even with this high margin of HR, which was chosen to incorporate investment risks, the project is economically feasible. Projects for converting the use of natural gas to the use of forestry biomass are economically viable due to the high costs of energy inputs. An essential portion of the natural gas used in the Brazilian industry comes from Bolivia, subject to changes and unexpected price increases when the government of that country nationalized the production plants. In the case of Scenario 1, where thermal and electric energy is produced, the benefit from the savings in the use of electric energy is high, due to the increase and readjustment of the tariffs necessary to rebalance the Brazilian electricity sector at the end of tariff control policy. Another reason for this result is the economy of the system scale (Upadhyay et al. 2012, Silva 2016). As the capacity of the system increases, there are increases in conversion efficiency, but at the same time, there is an increase in the cost of capital per unit of power produced because there are higher costs for biomass acquisition and transport (Akthari et al. 2014). In this investment project, the costs of acquiring and transporting forestry biomass are not similar because the project uses the leftovers from fiber sheet production. Studies indicate that the larger the scale of the system is, the lower is the cost of per generated electricity (MW); the magnitudes of the two are inversely proportional due to the conversion efficiency (CE), moving from $30 \%$ CE up to $10 \mathrm{MW}$ plant until $42 \%$ CE up to 50 MW plant (Caputo et al. 2005). Although with production capacity similar to this study, an investment project of using forest residues from the timber industry (remains and trimmings, wood residues and chips, waste from lathed wood, and weakened sheet residues) for combustion thermal power generation in the municipality of Marcelândia (Mato Grosso-MT) presented NPV much lower than that obtained in this study (Preilipper et al. 2016). The economic-financial results show an NPV of US\$ 643000 for electrical power production of $5 \mathrm{MW}$. Although the electricity production capacity is similar to that considered in this study, Marcelândia's project was almost entirely financed, resulting in significant cash outflow in the form of interest payments at rates close to the project HR. Comparing the results of these investments with a smaller scale (1 MW) also highly financed in a wood 
furniture industry that generates residues such as chips and sawdust that are used as raw material for power generation, the project was not feasible from an economic point of view, with negative NPV and low IRR (Colle et al. 2016). It appears that in this case, the cost of financing was also high concerning other costs and the revenues obtained. Although studies in Brazil on the economic feasibility of using waste and forest biomass to generate thermal or electrical energy are scarce, the scale and the cost of capital seems to influence the economic viability of this type of investment. Another factor that may explain the economic feasibility of the system is the type of biomass used. Analyzing the calorific values of wastes from the furniture industry, including a mixture of MDF (medium density fiberboard) panels, agglomerates, and plywood with and without coating, solid wood residues, MDF residues, mixed residues from MDF panels, and fine powder from panel sanding, these materials have calorific values ranging from $16.8 \mathrm{MJ} \mathrm{kg}^{-1}$ to $19.74 \mathrm{MJ} \mathrm{kg}^{-1}$ and, in general, low ash content (Farage et al. 2013). These calorific values and the low ash content imply better burning quality and, consequently, greater equipment efficiency, thus justifying the reuse of waste. However, investments in biopower require long-term investments and their profitability is directly related to price variations in the fuel and power markets, which may affect the economic results of the enterprise (Tromborg et al. 2011). An analysis of woody biomass heat generation systems shows that economic-financial indicators such as Payback and IRR are strongly influenced by the cost of forestry biomass (Nicholls et al. 2015). Both studies aim to replace natural gas and nonrenewable resources, whose prices depend not only on the market but also on government power policies, which, according to the author, may affect the economic feasibility of investments.

\section{Conclusions}

The results show that the project described here is feasible according to the NPV analysis, which showed a positive result, as did the IRR results, which were higher than the MARR. Also, it was found that EPB is less than the duration of the project. The economic feasibility was verified in the scenarios of substitution of natural gas by forest biomass for thermal generation and the scenario of thermal and electric generation. Also, the project economic feasibility is affected by fluctuations in electricity and natural gas prices; its benefits are conditional depending on these input costs, and the forestry biomass opportunity cost. Besides, these fluctuations compel the investor to adopt an HR much higher than the interest rates practiced in the market.

\section{References}

Akhtari, S., Sowlati, T., Day, K., 2014: Economic feasibility of utilizing forest biomass in district energy systems - A review. Renew. Sustain. Energy Rev. 33: 117-127. https://doi. org/10.1016/j.rser.2014.01.058

ANEEL, Boletim de Informações Gerenciais - $4^{\circ}$ Trimestre de 2017: Available online: http://www.aneel.gov.br/documents/656877/14854008/Boletim+de+Informa\%C3\%A7\%C3 \%B5es+Gerenciais+-+4\%C2\%BA+trimestre+2017/44ee303527e5-0398-e7e3-c612ec4dc994 (accessed on 09.04.2019.)

Assaf Neto, A., 2001: Estrutura and análise de balanços: um enfoque econômico-financeiro. $6^{\text {th }}$ ed., Atlas: São Paulo.

Brand, M.A., 2010: Energia de Biomassa Florestal. In: Interciência, Rio de Janeiro, 131 p.

Brealey, R., Myers, S., 2019: Fundamentals of Corporate Finance. $10^{\text {th }}$ ed., McGraw-Hill: New York.

Calôba, G.M., Neves, C., 2008: Engenharia Econômica e Finanças. Elsevier, Rio de Janeiro.

Caputo, A.C., Palumbo, M., Pelagagge, P.M., Scacchia, F., 2005: Economics of biomass energy utilization in combustion and gasification plants: effects of logistic variables. Bioenergy and Biomass 28(1): 35-51. https://doi.org/10.1016/j.biombioe.2004.04.009

Colle, D.A.T., Zucchi, C., Casarotto, G., Sehnem, S., 2016: Viabilidade de Implantação de uma Caldeira para Cogeração de Energia a partir da Biomassa. Rev. Gest. Sustentabilidade Ambient. 5(1): 60-91. http://dx.doi.org/10.19177/rgsa. v5e1201660-91

EPE, Balanço Energético Nacional 2018: Available online: http://epe.gov.br/sites-pt/publicacoes-dados-abertos/publicacoes/PublicacoesArquivos/publicacao-303/topico-419/ BEN2018_Int.pdf. 2018, 13-42, (accessed on 10.04.2019.).

Eufrade-Junior, H.J., Guerra, S.P.S., Sansígolo, C.A., Ballarin, A.W., 2018. Management of Eucalyptus short-rotation coppice and its outcome on fuel quality. Renew. Energy 121: 309-314. https://doi.org/10.1016/j.renene.2018.01.033

Eufrade-Junior, H.J., Nakashima, T.G., Yamagi, F.M., Guerra, S.P.S., Ballarin, A.W., 2017: Eucalyptus short-rotation coppice for solid fuel production. Industrial Crops and Products 108: 636-640. https://doi.org/10.1016/j.indcrop.2017.07.025

FAOSTAT. Available online: http://www.fao.org/faostat/ en/\#data/FO (accessed on 20.03.2019).

Farage, R.M.P., Rezende, A.A.P., Silva, C.M., Nunes, W.G., Carneiro, A.C.O., Vieira, D.B., Rodrigues, C.L.S., 2013: Avaliação do potencial de aproveitamento energético dos resíduos de madeira e derivados gerados em fábricas do polo moveleiro de Ubá - MG. Ciênc. Florest. 23(1): 203-212. http:// dx.doi.org/10.5902/198050988454

Gitman, L.J., 2004: Princípios da Administração Financeira, $10^{\text {th }}$ ed., Pearson Education: São Paulo. 
IBÁ (Industria Brasileira de Árvores) Report 2019: Available online: https://www.iba.org/datafiles/publicacoes/relatorios/ iba-relatorioanual2019.pdf (accessed on 29.05.2020.).

Londo, M., van Stralen, J., Uslu, A., Mozaffarian, H., Kraan, C., 2018: Lignocellulosic biomass for chemicals and energy: an integrated assessment of future EU market sizes, feedstock availability impacts, synergy and competition effects, and path dependencies. Biofuels, Bioprod. Bioref. 12(6): 1065-1081. https://doi.org/10.1002/bbb.1926

Nicholls, D.L., Brackley, A.M., Parrent, D.J., 2015: Economic and environmental benefits of community-scale cordwood hydronic heaters in Alaska-three case studies. Gen Tech Rep PNW-GTR-924 Portland US Dep. Agric. For. Serv. Pac. Northwest Res. Stn. 22 p. https://doi.org/10.2737/PNWGTR-924

Pedroso, L.L.A., Silva, F.F., Melo, Á.M., Junior, M.E., Shimoya, A., Matias, Í.O., Souza, C.L.M., 2018: Demandas atuais e futuras da biomassa e da energia renovável no Brasil e no mundo/Current and future demands for biomass and renewable energy in Brazil and worldwide. Braz. J. Dev. 4(5): 19801996.

Preilipper, U.E.M., Dalfovo, W.C.T., Zapparoli, I.D., Maroubo, L.A., Mainardes, E.L., 2016: Aproveitamento do resíduo madeireiro na produção de energia termoelétrica no município de Marcelândia-MT. Desenvolv. e Meio Amb. 36: 411-428. http://dx.doi.org/10.5380/dma.v36i0.39802

Santos, A.M., 2018: Caracterização química da biomassa: potencial da palha da cana-de-açúcar para a produção de etanol de segunda geração. Thesis, Universidade Federal do Alagoas: Rio Largo, Rio Largo, AL.

Silva, A.C.M.R., 2016: Correlações de eficiência energética em função da potência de termelétricas a biomassa. Ungraduate Thesis, Bachelor's of Science, Universidade de Brasília, Brasília.

Sosa, A., Acuna, M., Mcdonnell, K., Devlin, G., 2015. Controlling moisture content and truck configurations to model and optimise biomass supply chain logistics in Ireland. Appl. Energy 137: 338-351. https://doi.org/10.1016/j.apenergy.2014.10.018

Souza, M.M., Silva, D.A., Rochadelli, R., Santos, R.C., 2012: Estimativa de poder calorífico e caracterização para uso energético de resíduos da colheita e do processamento de Pinus taeda. Floresta 42(2): 325-334. http://dx.doi.org/10.5380/ rf.v42i2.26593

Tolmasquim, M.T., 2016: Energia Termelétrica: Gás Natural, Biomassa, Carvão, Nuclear. EPE: 417 p.

Trømborg, E., Havskjold, M., Lislebø, O., Rørstad, P.K., 2011: Projecting demand and supply of forest biomass for heating in Norway. En. Pol. 39(11): 7049-7058. https://doi. org/10.1016/j.enpol.2011.08.009

Upadhyay, T.P., Shahi, C., Leitch, M., Pulkki, R., 2012: Economic feasibility of biomass gasification for power generation in three selected communities of northwestern Ontario, Canada. En. Pol. 44: 235-244. https://doi.org/10.1016/j.enpol.2012.01.047

(C) 2021 by the authors. Submitted for possible open access publication under the terms and conditions of the Creative Commons Attribution (CC BY) license (http://creativecommons.org/licenses/by/4.0/).

Received: November 21, 2019

Accepted: July 17, 2020
Authors' addresses:

André Gustavo Oliveira Souza, MSc e-mail: andre.souza@duratex.com.br Franklin de Souza Barbosa, BSc e-mail: franklin_barbosa@hotmail.co.uk Acocc prof. Maura Seiko Tsutsui Esperancini, PhD e-mail: maura.esperancini@unesp.br Assist. prof. Saulo Phillipe Sebastião Guerra, PhD * e-mail: saulo.guerra@unesp.br School of Agronomical Sciences São Paulo State University - UNESP

Avenida Universitária, 3780

Botucatu-SP, 18610-034 BRASIL

* Corresponding author 